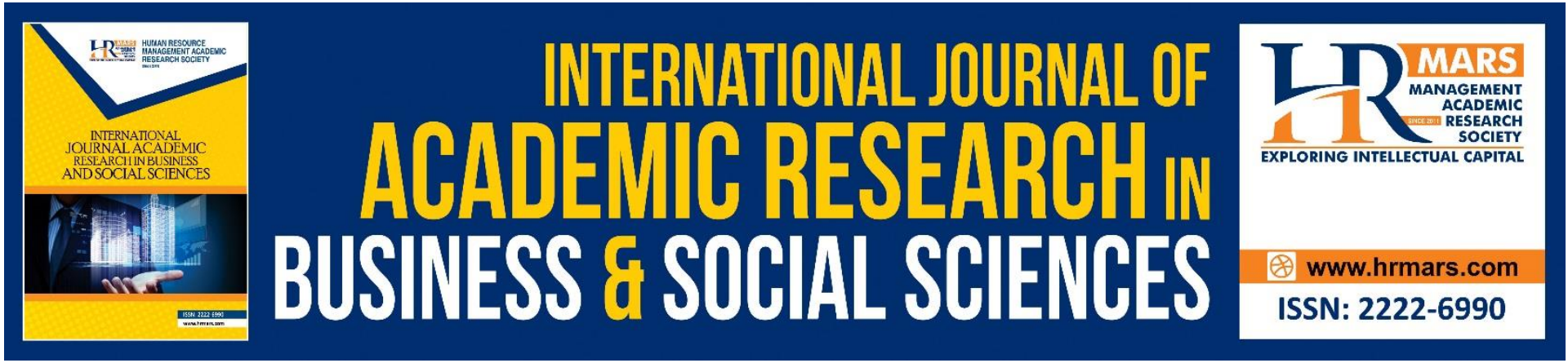

\title{
The Attorney General's Exercise of Prosecutorial Discretion in Malaysia: A Critique of Scope, Limitation and Challenges
}

\section{Habibah Omar}

To Link this Article: http://dx.doi.org/10.6007/IJARBSS/v11-i10/11279

DOI:10.6007/IJARBSS/v11-i10/11279

Received: 08 August 2021, Revised: 05 September 2021, Accepted: 22 September 2021

Published Online: 01 October 2021

In-Text Citation: (Omar, 2021)

To Cite this Article: Omar, H. (2021). The Attorney General's Exercise of Prosecutorial Discretion in Malaysia: A Critique of Scope, Limitation and Challenges. International Journal of Academic Research in Business and Social Sciences, 11(10), 1355-1371.

\section{Copyright: (c) 2021 The Author(s)}

Published by Human Resource Management Academic Research Society (www.hrmars.com)

This article is published under the Creative Commons Attribution (CC BY 4.0) license. Anyone may reproduce, distribute, translate and create derivative works of this article (for both commercial and non-commercial purposes), subject to full attribution to the original publication and authors. The full terms of this license may be seen

at: http://creativecommons.org/licences/by/4.0/legalcode

Vol. 11, No. 10, 2021, Pg. $1355-1371$

Full Terms \& Conditions of access and use can be found at http://hrmars.com/index.php/pages/detail/publication-ethics 


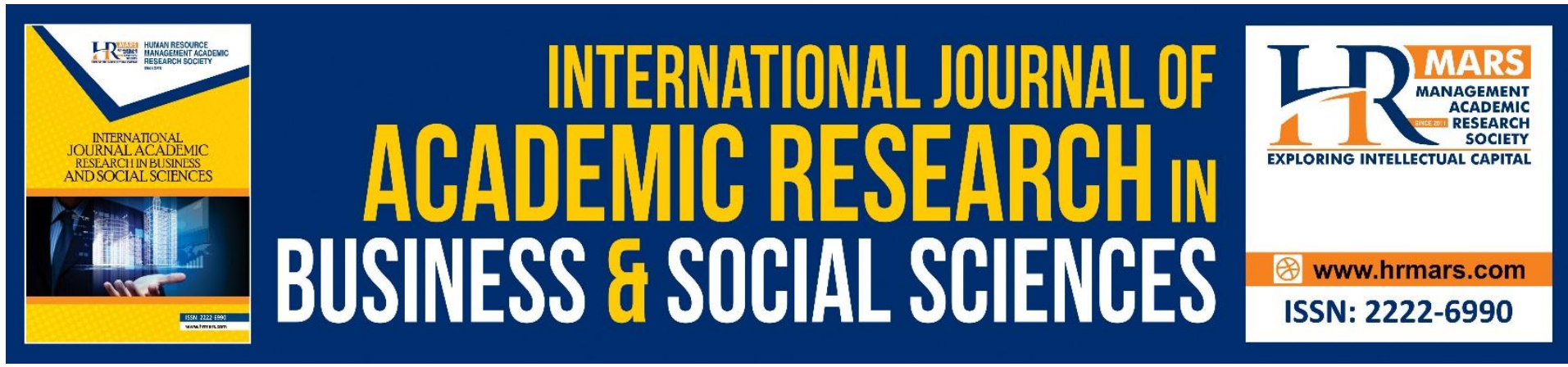

\title{
The Attorney General's Exercise of Prosecutorial Discretion in Malaysia: A Critique of Scope, Limitation and Challenges
}

\author{
Habibah Omar \\ Faculty of Law, Universiti Teknologi MARA, Malaysia \\ Email: habib597@uitm.edu.my
}

\begin{abstract}
The dual role played by the Attorney General of Malaysia as the legal advisor for the government and the person who decides on whether criminals are prosecuted, raises the question whether he can discharge his duties impartially and objectively, especially when deciding whether to prosecute high ranking members of the government for crimes. This paper seeks to address the potential conflict that may arise from the existence of this dual role, is the scope of the prosecutorial discretion, the limits placed upon it by the law and whether the Attorney General can claim immunity in respect of the consequences of the exercise of his discretion. The paper comprises of doctrinal analysis on the scope of discretionary power of the Attorney General and through comparative analysis of several other jurisdictions, examines the trend and contemporary approach on the exercise of such power. It is found that the judiciary in the exercise of judicial review is keen on maintaining the status quo, despite attempts of more progressive approach. This paper provides some recommendations of the Attorney General's prosecutorial role on a proper exercise of discretion, promoting transparency as decisions shrouded in secrecy diminished the standing of the Attorney General's office.
\end{abstract}

Keywords: Attorney General, Public Prosecutor, Prosecutorial Discretion, Prosecutorial Immunity

\section{Introduction}

In recent years, the exercise of power by the Attorney General is increasingly being scrutinized. Some decisions made by him had generated much discussion, publicity, and debate by the public at large and by the members of the legal fraternity. The Attorney General's exercise of the power to prosecute is questioned and his claim of protection under the umbrella of prosecutorial immunity is frown upon. Challenges have been made in courts to question the Attorney General's exercise of discretion and his claim of prosecutorial immunity (See Dato'Pahlawan Ramli bin Yusoff v Tan Sri Abdul Gani bin Patail [2014] 4 MLRH 573; Rosli bin Dahlan v Tan Sri Abdul Gani bin Patail \&Ors [2014] 11 ML 481). Thus, succeeding the general outline of the methodology, this paper will address the above issues in several sections. First, the paper will look at the concept of discretion, and the dual role played by the Attorney General and the power accorded to him by law. Secondly, the scope 
and limits of the Attorney General's prosecutorial discretion will be examined and whether the Attorney General can claim immunity in respect of the consequences of the exercise of his discretion. The third part of this paper will provide some recommendations to improve the Attorney General's standing in the eyes of the public and hence restoring the confidence of his role in the Malaysian Criminal Justice system.

\section{Methodology}

This paper is a qualitative research paper and prepared following the doctrinal research approach. This approach focuses on the systematic elaboration of the rules and principles which aims to describe the existing law and its authoritative characteristics, which can eventually validate proposed solution (Smits, 2017). This method is levelled at understanding the black letter law from the primary sources i.e. of the Federal Constitution of Malaysia, relevant statutes, case laws and scholarly journals. This doctrinal study is combined with the comparative legal analysis with the aim of learning from others. According to Hoecke (Hoecke, 2016) comparative study is a useful tool to inquire whether our law is at parallel with the development and evolution other countries. Indeed, for this paper, the understanding of the law and legal position of the Attorney General in the Federal Constitution is paramount important before learning for a possible improvement from other jurisdictions.

\section{Discussion}

What is discretion? Discretion, according to Judge Marvin Frankel - is law without order (Frankel, 1973). It has been viewed increasingly suspiciously by the people (Stith, 2008). It is regarded as a residual concept where subjective judgment can be exercised by statutes, rules, or judicial decisions (Yang, 2013). Hence, some exercise of administrative actions, in particular, that of the Attorney General will be impossible without a degree of discretion. It is the Attorney General that determines the course of criminal process; hence he has to employ his discretion to reach that decision and eventually to date, the scope of prosecutorial discretion is increasingly expanding (Krug, 2002). In this context, the scope and extent of the exercise of the Attorney General's discretionary powers in Malaysia need to be explored.

\section{Attorney General's Dual Role: Functions, Authority, and the Apparent Conflict}

The debate on the actions of this top legal personnel may stem from the double responsibilities the Attorney General plays in Malaysia. First, he is the chief legal advisor to the federal government who is responsible for representing and protecting the interest of the government. In the performance of his duty as an independent legal advisor, he must uphold the rule of law that protects individuals and society while making sure that the government is acting legally and constitutionally.

Secondly, the Attorney General acts as the public prosecutor who is responsible under the criminal justice system to prosecute individuals for crime. In the performance of such responsibility, the Attorney General must ensure that decisions to initiate criminal actions are objectively made, conforming to the legal criteria, free of any political considerations.

Both roles of the Attorney General are accorded by statutory law and decided cases and are constitutionally outlined. Article 145(2) of the Federal Constitution accords the Attorney General the responsibility to advise the Yang di-Pertuan Agong, the Cabinet, or any Minister 
on any legal matters. It will be within his responsibility to defend the government or take an action on behalf of the government in matters of civil litigation (Sheridan and Groves, 1987).

Besides, Article 145(3) also empowers the Attorney General to act as Public Prosecutor. As Public Prosecutor, The Attorney General has the authority "to exercise his discretion to institute, conduct or discontinue any criminal proceedings". Unfortunately, the Federal Constitution does not specify in detail the character and extent of the Attorney General's discretionary power. Similarly, the Criminal Procedure Code, in particular, section 376(1) which empowers the Attorney General to exercise control over all criminal prosecutions (not only under the Penal Code but also any other law), does not provide any detailed mechanism on how the discretion is to be exercised. There have been no published guidelines outlining how the Attorney General's discretion is to be applied in deciding whether to prosecute or not, or whether to order nolle prosequi and under which law should a person be charged. Besides, judges in Malaysia have been very reluctant to encroach into the Attorney General's exercise of powers in this context. Nonetheless, obligations in the conduct of criminal prosecutions is seen as an obligation to represent the public interest. Interests of the public, the victim and the accused person himself have to be balanced. This is on the basis that in a criminal action, the State is taking charge to protect the public but at the same time, must accord a fair trial for the accused.

The combined responsibility of providing legal advice and representing the government of the day could at times be at a crossroad with his responsibility as a public prosecutor (Abu Bakar 2015). The possible conflict of interests is real, especially when contemplating whether to prosecute high-ranking officials of the government. There have been several investigations of high-profile cases where no prosecution takes place. Attorney General's position as a political appointee and his accountability only to the Prime Minister may impact his decision whether to prosecute or not. This is due to the constitutional position of the Attorney General has undergone several amendments to reduce his position from that of quasi-judicial to that of an exclusive servant of the executive, in particular, the Prime Minister. This was expressed in Datuk Haji Harun Bin Haji Idris v Public Prosecutor that the Attorney General's act of discretion under Article 145(3) is not of judicial power, but executive.

Indeed, the experience of Malaysia in the past few years seems to suggest the non-partiality of the Attorney General in exercising his prosecutorial power. Such an occurrence is not something new or unique to Malaysia. Lochner (2002) suggests that in exercising prosecutorial discretion, prosecutors are indeed behaving strategically to benefit them personally or professionally. They may aim for a more secured and lucrative future employment (Eisenstein, 1978) and prefer complex and high-profile cases to enhance their "marketability" (Eisenstein, 1978; Glaeser, Kessler, and Piehl, 2000). Some perhaps may prefer to apple-polish their superior. Despite the commitment to independence, the prosecutors (and in the context of this paper, the Attorney General) are at times, consider political factors in deciding to prosecute. This unfortunately can undermine the confidence and trust of the public in the government of the day (Boyd et al., 2021).

VC George J explained the position of the Attorney General in Malaysia in Lim Kit Siang $v$ United Engineers (M) Bhd \& 3 Ors [1988] 1 ML 50 that, 
In Malaysia, the Attorney-General's position is very different from that of his British counterpart. He is a civil servant appointed by His Majesty the Yang Di Pertuan Agong on the advice of the Prime Minister. He is not answerable to anybody, not to any Minister or Ministry, not even to the Prime Minister, not to Parliament and not to the people (in that his is not a political appointment). However, he holds office during the pleasure of the Yang Di Pertuan Agong which in effect means during the pleasure of the Executive.

The role performed by the Attorney General as the government's legal advisor and appears as counsel for the government placed him in a difficult position, having to draw the line on the right of the litigant and that of the government as the interest sometimes conflict when a litigant takes action against the government. Thus, when relators embarked on public interest litigation, Attorney General was put in an awkward situation to decide whether to allow such actions. This creates an embarrassment for the Attorney General. The need for Attorney General's consent in initiating relators' actions is regarded as archaic and impracticable as it is common sense that Attorney General's action will reflect the will of his masters. This may be indeed a political decision.

\section{Exercise of the Attorney General's Prosecutorial Discretion}

The prosecutorial power of the Attorney General relating to criminal prosecution is referring to his discretion to refuse, initiate or discontinue criminal prosecution and what charge to be imposed in situations where evidence is sufficient, and prosecution is in the public interest (Boolell, 2013). Judicial interventions on the exercise of such power worldwide, have been very limited with the extreme exercise of caution due to the doctrine of separation of powers. Concerns for leniency, efficiency, practicability, and acknowledgment of the impossibility of total enforcement of the law; upon reflecting the nature of the function of an Attorney General require the discretion to be exercised in good faith (Applegate, 1982; Chan, 2013) Hence, the deciding criminal prosecution, the Attorney General must ensure that decisions to initiate criminal actions are objectively made, conforming to the legal criteria, free of any irrelevant considerations.

The historical outlook of the Attorney General's prosecutorial discretion Article 145(3) outlines the prosecutorial power of the Attorney General. Earlier cases indicate that such discretion is unfettered. It was decided in the Federal Court's Long bin Samat \& Ors v Public Prosecutor [1974] 2 ML 152 (FC), where Suffian LP stated that:

In our view, this clause from the supreme law clearly gives the Attorney-General very wide discretion over the control and direction of all criminal prosecutions. Not only may he institute and conduct any proceedings for an offence, he may also discontinue criminal proceedings that he has instituted, and the courts cannot compel him to institute any criminal proceedings which he does not wish to institute or to go on with any criminal proceedings which he has decided to discontinue. (For the position in England, please see Viscount Dilhorne's speech at pages 32-3 in Smedleys Ltd v Breed [1974] 2 All ER 21). Still less then would the court have power to compel him to enhance a charge when he is content to go on with a charge of a less serious nature.

Anyone who is dissatisfied with the Attorney-general's decision not to prosecute, or not to go on with a prosecution or his decision to prefer a charge for a less serious offence when 
there is evidence of a more serious offence which should be tried in a higher court, should seek his remedy elsewhere, but not in the courts.

This decision reflects that such exercise of prosecutorial authority is not justiciable and of no concern for judicial control. This has been quoted with approval in later cases. See Johnson Tan Han Seng v Public Prosecutor [1977] 2 ML 66, FC; Soon Seng Sia Heng v Public Prosecutor [1977] 2 MLJ 66, FC ; Teh Cheng Poh v Public Prosecutor [1979] 1 ML 50 (PC); PP v Lee Tin Bau [1985] 1 ML 388; PP v Zainuddin \& Anor [1986] 2 ML 100 . The Federal Court regards such discretion as complete (see PP v Lau Kee Hoo [1983] 1 MLJ 157). Thus, Attorney General has the power to initiate any action and prosecute any criminal cases. This power extends to giving consent to any request for prosecution (see Pai San \& Ors v Public Prosecutor [2002] 4 MLJ 538).

Eventually, in Repco Holdings Bhd v Public Prosecutor [1997] 3 ML 681, the decisions of Long bin Samat and Johnson Tan Han Seng were summed up with approval when Justice Gopal Sri Ram (then) expressed that:

The importance of the propositions formulated by the learned Lord President in these two cases is that, as a matter of public law, the exercise of discretion by the Attorney General in the context of art 145(3) is put beyond judicial review. In other words, the exercise by the Attorney General of his discretion, in one way or another, under art 145(3), cannot be questioned in the courts by way of certiorari, declaration or other judicial review proceedings.

I think that the proposition is not only good law but good policy. For, were it otherwise, upon each occasion that the Attorney General decides not to institute or conduct or discontinue a particular criminal proceedings, he will be called upon to a court of law the reasons for his decision. It will then be the court and not the Attorney General who will be exercising the power under art 145(3). That was surely not the intent on our founding fathers who framed our Constitution for us.

This case seems to seal the fate that the discretion exercised by the Attorney General is far beyond the touch of the judiciary to even question it under judicial review. In fact, in a more recent Court of Appeal decision in Mohd Rafizi bin Ramli v Public Prosecutor [2014] 3 ML 114 , it was held that the courts ought to refrain from inquiring into the Attorney General's power under Article 145(3) where it was said:

A judge must keep out of the arena. He should not have or appear to have any responsibility for the institution of a prosecution. The functions of prosecutors and of judges must not be blurred. If a judge has power to decline to hear a case because he does not think it should be brought, then it soon may be thought that the cases he allows to proceed are cases brought with his consent or approval.

This was followed in Khairuddin bin Abu Hassan $v$ Tan Sri Mohamed Apandi Ali (Sued in his capacity as the appointed Attorney General) [2017] 9 MLJ 441 confirming the Attorney General's unfettered and absolute power relating to criminal prosecution. 
The rationalization for the exercise of such discretion

The justifications for the allowance of such exercise of discretion are mainly founded on two grounds: First, the concept of rule of law and adherence to the doctrine of separation of powers. Secondly, the Attorney General is presumed to have exercised his discretion constitutionally.

The office of the Attorney General and the judiciary enjoy equal status. They are not supposed to encroach into each other's functions duly outlined in the Federal Constitution but will have a degree of check and balance between them. Encroachment of the judiciary on the decisions related to institution of criminal proceedings goes against the basis of the separation of powers' doctrine which provides the foundation for the rule of law. As stated by Viscount Dilhorne in Director of Public Prosecutor v Humprys [1977] AC 1 at $p$ 26,

A judge must keep out of the arena. He should not have or appear to have any responsibility for the institution of a prosecution. The functions of prosecutors and of judges must not be blurred. If a judge has power to decline to hear a case because he does not think it should be brought, then it soon may be thought that the cases he allows to proceed are cases brought with his consent or approval.

The learned Lord Salmon in the same case further stated that:

I respectfully agree with my noble and learned friend, Viscount Dilhorne, that a judge has not and should not appear to have any responsibility for the institution of prosecutions; nor has he any power to refuse to allow a prosecution to proceed merely because he considers that, as a matter of policy, it ought not to have been brought. It is only if the prosecution amounts to an abuse of the process of the court and is oppressive and vexatious that the judge has the power to intervene. Fortunately, such prosecutions are hardly ever brought but the power of the court to prevent them is, in my view, of great constitutional importance and should be jealously preserved. For a man to be harassed and put to the expense of perhaps a long trial and then given an absolute discharge is hardly from any point of view an effective substitute for the exercise by the court of the power to which I have referred. (at $p$ 46.)

Thus, the above judgment suggests that the exercise of the Attorney General's discretion to prosecute can only be questioned on the ground of misuse of the court's process where the action is regarded as oppressive and vexatious. In Hui Chi-Ming v R [1992] 1 AC 34 at p 57, the Privy Council defined abuse of process as "something so unfair and wrong the court should not allow the prosecutor to proceed with what is in all other respects a regular proceeding". To be successful in this claim, the party who makes the allegation must furnish the necessary evidence for example, of fraud or deceit.

Secondly, when the Attorney General exercises his power, he is presumed to be acting constitutionally. This presumption stems from the doctrine of separation of power (Chan, 2013). Attorney General is accorded with wide discretionary power due to the existence of a presumption i.e., whenever the Attorney General applies his discretion, it is presumed to be constitutionally and validly exercised under the law. It has been judicially pronounced that in the pursuit of maintaining the rule of law, there must be no suspicion that Attorney General acted dishonestly. Hence, the law presumes that Attorney General acts in the best interest 
of the general public and that it is done in good faith (Fisher, 1993). It is prudent for the court to presume that the Attorney General's decisions are constitutional and valid until otherwise is shown (See Law Society of Singapore v Tan Guat Neo Phyllis [2008] 2 SLR(R) 239).

In Johnson Tan Han Seng v Public Prosecutor [1977] 2 MLJ 66, a challenge on Attorney General's decision was made under Article 8. It was decided that the Attorney General must be assumed by the public, to act honestly, without fear of powerful individuals, and regard to his political consequences. The Attorney General must act without favoring his relatives, friends, and supporters as his principal concern are to preserve the rule of law and to uphold standards and trust of both the public and private life.

This proposition of law permits the Attorney General to reign supreme on the matter relating to criminal prosecution. This indeed gives rise to concern. Some actions and decisions by the Attorney General are shrouded in secrecy and there is no obligation for the Attorney General to give reasons for his decisions. This, unfortunately, resulted in executive authorities (like Attorney General) free to run loose in exercising unchanneled and unreviewable discretion in secrecy. Such decisions are essentially lawless because they are beyond the power of law to control. In the context of Malaysia, judicial review is not only limited but almost totally absent in providing checks on Attorney General's decisions and actions. Although there may be an evidential test that is applied in deciding whether to prosecute or not, the second public interest consideration provides a high opportunity for discretion to overrule the use of those tests. The Shawcross Guideline which most Attorney Generals are guided by stressed that it has never been the rule that criminal offenses to be mechanically subject to prosecution (House of Commons, 1951).

Legal Limits to the Exercise of the Attorney General's Prosecutorial Discretion in Malaysia Power tends to corrupt, and absolute power corrupts absolutely. Great men are almost always bad men (Lord Acton, 1887). The idea that a person enjoys absolute discretion and not amenable to judicial review seems to go against the very fabric of rule of law. In fact, since the 1980's, there have been move towards scrutinizing the Attorney General's exercise of discretion.

There are indeed legal limits to the Attorney General's power. In Singapore, upon reading its Article 35(8) of the Singapore's Constitution (which is in pari materia with Article 145(3) of the Malaysian Federal Constitution), the courts acknowledged two legal limits to the Attorney General's prosecutorial discretion, namely, an encroachment of constitutional rights and decisions made in bad faith. By reading the celebrated case of Council of Civil Service Unions and Others v Minister for the Civil Service [1985] A.C. 374 (CCSU's case) into the issues at hand, challenging administrative or executive's actions on the ground of bad faith is equivalent to challenging the act of the executive for abuse of power under the ground of irrationality (Chan, 2013).

Lord Diplock at page 410 of the CCSU's case states that, By "irrationality" I mean what can by now be succinctly referred to as "Wednesbury unreasonableness" (Associated Provincial Picture Houses Ltd. v. Wednesbury Corporation [1948] 1 K.B. 223). It applies to a decision which is so outrageous in its defiance of logic or of accepted moral standards that no sensible person who had applied his mind to the 
question to be decided could have arrived at it. Whether a decision falls within this category is a question that judges by their training and experience should be well equipped to answer, or else there would be something badly wrong with our judicial system. To justify the court's exercise of this role, resort I think is today no longer needed to Viscount Radcliffe's ingenious explanation in Edwards v. Bairstow [1956] A.C. 14 of irrationality as a ground for a court's reversal of a decision by ascribing it to an inferred though unidentifiable mistake of law by the decision-maker. "Irrationality" by now can stand upon its own feet as an accepted ground on which a decision may be attacked by judicial review.

Limits to prosecutorial discretion on the grounds of unconstitutionality

The exercise of the Attorney General's discretion has been challenged several times for encroaching into individual's constitutional rights entrenched in the Federal Constitution.

\section{The tugs-of-war were between Article 145(3) and the equality provision in Article 8}

The Federal Constitution, Article 8 provides for equality before the law and equal protection of the law. This provision implies that all citizens are subject to the same kind of law in the country where every individual, regardless of his official position or social standing are to be treated alike. This equality provision aims towards minimizing tyranny. The court as a guardian of rights must bear the responsibility in upholding this equality law. In emphasizing the court's duty, Abdul Hamid, J in the case of Public Prosecutor v Tunku Mahmood Iskandar [1977] 2 MLJ 123 states that,

Let me make it abundantly clear that I have, in view of the circumstances of the present case, given considerable thought to the concept of equality before the law as enshrined under our Constitution. It bears great significance and the court as guardian of the law must not lose sight of it. There is always an inherent danger that the concept would lose its significance if persons brought before the court are treated discriminately. It is upon this fundamental entrenchment of the basic right, namely, all persons are equal before the law, that lies the strength of our system, the dignity and resourcefulness of our people and the independence of our Judiciary. With equality there is, I concede, the corresponding right or entitlement to equal protection of the law. Viewed upon such premises I find the institution of a prosecution against the accused before a Court of Justice an affirmation, indeed a testimony of our firm conviction in the rule of law. It is not my intention to preach or offer advice to the accused but to emphatically create awareness in his mind that there is a lesson to be learnt, that in a country where we take comfort in an excellent Constitution, where the rule of law prevails, no man can act in disobedience to and conceivably claim that he can take the law into his own hands.

This case was highly regarded as the Attorney General initiated criminal prosecution against a member of a Royal family without considering his social status confirming him to have full control and direction of all criminal prosecutions and proceedings. Article 8 cannot be the basis to challenge such Attorney General's exercise of discretion.

In the Federal Court case of Public Prosecutor v Khong Teng Khen \& Anor [1976] 2 ML 166 at p 170, Suffian, LP stated that, 
The principle underlying Article 8 is that a law must operate alike on all persons under like circumstances, not simply that it must operate alike on all persons in any circumstance, nor that it 'must be general in character and universal in application and that the State is no longer to have the power of distinguishing and classifying persons .... for the purpose of legislation'; Kedar Nath v State of West Bengal AIR 1953 SC 404 406. In my opinion, the law may classify persons into children, juveniles and adults, and provide different criteria for determining their criminal liability or the mode of trying them or punishing them if found guilty; ... the law may classify offences into different categories and provide that some offences be triable in a Magistrate's court, others in a Sessions Court, and yet others in the High Court... and yet in my judgment in none of these cases can the law be said to violate Article 8. All that Article 8 guarantees is that a person in one class should be treated the same as another person in the same class, so that a juvenile must be tried like another juvenile..., and so on.

Thus, this case suggests that there can be lawful discrimination based on the 'reasonable classification test' where persons in like circumstances must be treated alike. In Teh Cheng Poh v PP [1979] 1 ML 50 (PC), the Attorney General used his discretion and prosecute the accused under section 57(1) of the Internal Security Act, 1964 that imposed a mandatory death upon conviction as opposed to other statutes such as the Arms Act, 1960 and the Firearms (Increased Penalties) Act, 1971 which provide for lesser punishments. Such exercise of discretion was held to be lawful as there was no evidence to suggest otherwise. According to the Lordships, even if the Attorney General had to charge the appellant under three statutes, the choice ceases to be exercised once the Attorney General opts to charge the appellant under one law. Once he chose the Internal Security Act 1960, he hence had no option but to frame the charge under the Internal Security Act, 1960.

This is reflected in Mat Shuhaimi bin Shafiei v Public Prosecutor [2014] 2 MLJ 145 where it was expressly held by the Court of Appeal that Article 8 of the Federal Constitution does not require that person accused of comparable offences be charged under the same statute. Such discrimination by the Attorney General is allowed and will not be regarded as contrary to Article 8. As illustrated in the case of Poh Cho Ching v Public Prosecutor [1982] 1 MLJ 86, the Attorney General was held to have the discretion to prosecute those who accepts bribe and not the contributor of bribes, and this is a non-violation of Article 8(1). Such exercise of discretion was seen in cases like Public Prosecutor $v$ Yee Kim Seng [1983] 1 MLJ 252 and Teh Cheng Poh v PP [1979] 1 ML 50 (PC) where it is the Attorney General's will to choose the Act under which charges will be founded.

Indeed, the decision in Mat Shuhaimi reflected the Court of Appeal's strong preference of not wishing to intrude with the Attorney General's exercise of prosecutorial decision making and to treat such discretion as purely valid and absolute. Not only that the court decided that it could not inspect into the reasons of the Attorney General's determination, but the court also decided that it was prevented from inquiring into the merit of the exercise of the Attorney General's discretionary power. A recommendation was also made whereby in the event of aggrieved by the Attorney General's decision, the individual should channel the complaint or dissatisfaction to the Attorney General himself (also see Long bin Samat v Public Prosecutor [1974] 2 MLJ 152). In fact, the court in Johnson Tan Han Seng move on to suggest that if the Attorney General had failed to perform his duty honorably and honestly, the public can 
demonstrate them politically by voting against the party of which he is a member. The resolution, hence, does not lie in in the courts.

With regards to Attorney General's power to choose which court a case is brought, the case of Nadarajah v Public Prosecutor [2000] 4 MLJ 373 can be of guidance. On page 381, the court states that,

All that equality before the law requires is that the cases of all potential defendants to criminal charges shall be given unbiased consideration by the prosecuting authority and that decisions whether or not to prosecute in a particular case for a particular offence should not be dictated by some irrelevant consideration (see Teh Cheng Poh v PP [1979] 1 MLJ 50). Thus as Lord Diplock said in Ong Ah Chuan v PP [1981] 1 ML 64, Article 8(1) of the Constitution does not forbid discrimination in punitive treatment between one class of individuals and another class in relation to which there is some difference in the circumstances of the offence that has been committed. The decision to identify the difference in the circumstances of a particular case and to act accordingly is that of the Attorney General pursuant to Article 145(3) of the Constitution and is not subject to judicial review (see Repco Holdings Bhd v PP [1997] 3 MLJ 681). In any event the exercise of the discretion by the Attorney General to institute a prosecution against a person in a certain court, dependent on the circumstances of that case, may itself amount to a reasonable classification for the purposes of Article 8(1) of the Constitution. Cases such as Ramkrishna Dalmia v Tendolkar [1959] SCR 279, Govindlalji v State of Rajasthan [1964] 1 SCR 561, State of J \& K v Golam Md AIR 1967 SC 122, Birakishore v State of Orissa(1964) 7 SCR 32, Mittal v Union of India AIR 1983 SCI and Lachman v State of Punjab AIR 1963 SC 222 support the proposition that a classification may be reasonable even though a single individual is treated as a class of himself, if there are some special circumstances or reasons applicable to him alone and not applicable to others. The objection grounded on Article 8(1) of the Constitution cannot therefore be sustained.

Thus, it can be concluded here that Article 8 of the Federal Constitution failed as a ground in challenging the Attorney General's prosecutorial power to initiate or discontinue criminal proceedings, to choose the court in which the action is initiated, and to opt to charge the offender under one statute over the other. Such protection of equality before the law only obligates the Attorney General to give impartial consideration to criminal offenders and to make sure that in exercising his prosecutorial discretion, he did not take into account irrelevant considerations.

\section{Limits to Attorney General's Prosecutorial Discretion: Irrationality or Abuse of Power}

As the Attorney General exercises his power to prosecute under Article 145(3), the Attorney General is exercising an executive power (see Datuk Haji Harun Bin Haji Idris v Public Prosecutor [1977] 2 ML 155; Lim Kit Siang v United Engineers (M) Bhd \& 3 Ors [1988] 1 MLJ 50) (Baharuddin, 2015). Executive actions and quasi-judicial actions can be challenged on the ground of irrationality or abuse of power. These are well-established principles. In Connelly v. Director of Public Prosecutions [1964] A.C. 1254, 1296, there must always be a residual discretion to prevent anything which savours of abuse of process (per Lord Reid). Hence, when considering criminal prosecution, the Attorney General should bear in mind the public interest. 
Due to the exclusive quality of the Attorney General's authority in the direction and control of criminal matters, it is expected of him to exert his preference honestly and professionally. He is entrusted by law to exercise his power exclusively that such decision is not susceptible to any judicial review. Hence, he is expected to discharge his power bona fide and professionally in that when he prefers a charge against an individual, he does so because public interest demands that prosecution should be initiated and when he refrains from charging an individual or discontinues a prosecution already initiated, he also acts upon the dictate of public interest (as per Salleh Abas, LP in Public Prosecutor v Zainuddin \& Anor [1986] 2 MLJ 100).

Despite popular understanding, the Attorney General's discretion can be challenged on the grounds of irrationality. In the Privy Council decision of Teh Cheng Poh $v$ Public Prosecutor [1979] 1 MLJ 50 (PC), it was expressed that:

There are many factors which a prosecuting authority may properly take into account in exercising its discretion as to whether to charge a person at all, or, where the information available to it discloses the ingredients of a greater as well as a lesser offence, as to whether to charge the accused with the greater or the lesser. The existence of those factors to which the prosecuting authority may properly have regard and the relative weight to be attached to each of them may vary enormously between one case and another. All that equality before the law requires, is that the cases of all potential defendants to criminal charges shall be given unbiased consideration by the prosecuting authority and that decisions whether or not to prosecute in a particular case for a particular offence should not be dictated by some irrelevant consideration.

It is submitted that only when the power is exercised as such (i.e. non-existent of abuse of power) that the Attorney General enjoys absolute and unfettered discretion to prosecute. It is also submitted that, when there is an allegation of mala fide, such allegation can only sustain and succeed upon production of clear proof or evidence.

This state of law has been decided in a landmark case of Dato' Pahlawan Ramli bin Yusoff $v$ Tan Sri Abdul Gani bin Patail [2014] 4 MLRH 573; Rosli bin Dahlan v Tan Sri Abdul Gani bin Patail \& Ors [2014] 11 MLJ 481 where, for the first time, the Attorney General failed in relying on prosecutorial immunity and his exercise of prosecutorial discretion was challenged in a civil claim.

In Rosli bin Dahlan's case, the Attorney General, with the assistance from Malaysian AntiCorruption Commission and several other individuals, had wrongfully caused the Plaintiff to be investigated and later charged under the corruption law. They also caused false information to be published by various mainstream and alternative media about the alleged offence he committed. He was however acquitted of all charges made against him.

In retaliation, the plaintiff brought an action against the defendants for conspiracy, false and malicious investigation, abuse of power, abuse of prosecutorial discretion, malicious prosecution and prosecutorial misconduct, and public misfeasance. The Attorney General reacted by filing to strike out the suit on several grounds and one of which is that his discretion 
is non-justiciable and that it was absolute i.e., the Attorney General enjoys absolute prosecutorial immunity.

Vanzeer Alam Mydin, JC, in his judgment, analyzed the position of unfettered discretions of public officials, Attorney General's power and assertion of immunity as well as the approach of other jurisdictions and stated that:

... there is tacit acknowledgment that though prosecutorial authority is constitutionally vested in the Attorney General, the prosecutorial discretion must be exercised for its proper constitutional purpose and not for some unlawful or improper purpose. And that proper constitutional purpose is to uphold the rule of law by enforcing criminal law, as well as maintaining law and order for the greater good of society. Now, if the Attorney General as the custodian of prosecutorial power exercises his prosecutorial discretion for other than its constitutional purpose or exercises it based on some irrelevant consideration or exercises his discretion unlawfully or the prosecutorial power is abused for some improper purpose, then that decision can become justiciable and the courts have a duty to render assistance to an individual who has been aggrieved by that decision.

Hence, it can be concluded that the discretion of the Attorney General is not absolute. Such discretion is qualified the moment it is exercised dubiously.

\section{Can the prosecutorial discretion of Attorney General be challenged upon transgression of the Constitution's basic structure?}

Two recent cases on constitutional law revive the possibility of challenging the deemed unchallenged discretion of the Attorney General. There are Semenyih Jaya $v$ Pentadbir Tanah Hulu Langat and another case [2017] 3 MLJ 561 and Indra Ghandi v Pengarah Jabatan Agama Islam Perak\& Ors and other appeals [2018]1 MLJ 545. Though these cases did not directly deal with issues of Attorney General prosecutorial power, they opened a backdoor on challenging such discretion (Shahizam, 2020).

In both cases, the power of judicial review of the court is regarded as inherent and hence an embodiment of the basic structure of the Federal Constitution. Such authority, according to the Federal Court Judge, Justice Zainun Ali, cannot be abrogated or altered even through a constitutional amendment (see Indra Ghandi's case). On this note, Shahizam (2020) contends that being part of the Constitution's basic structure, the judges can exercise their review power even to that exercised by the Attorney General. This is part and parcel of the doctrine of separation of powers.

This is indeed an attractive argument to be put forward in the event the prosecutorial discretion of the Attorney General is again challenged in court. The power of judicial review of the courts in Malaysia is constitutionally enshrined in Articles 4(1), 75, 128, and 162(2) of the Federal Constitution. It is indeed through the power of judicial review, judges are task to preserve, protect and defend the Constitution from any possible attack, including the inappropriate exercise of discretionary power. These are indeed signs of a positive outlook on this issue. 
The development of the law on the exercise of discretionary powers in other jurisdictions such as the United Kingdom, Australia, Canada, and to some extent, Singapore, is conspicuous. In those countries, the Attorney General's discretionary power relating to criminal prosecution is subject to judicial review. With exception to Singapore, in guiding the exercise of prosecutorial decision, the United Kingdom, Australia and Canada already formulated prosecutorial guidelines that are opened to the public to afford consistency, transparency, and accountability in the utilization of the Attorney General's discretion.

\section{Recommendations}

Justice William Douglas put it, "Absolute discretion, like corruption, marks the beginning of the end of liberty." Indeed, the use of discretion cannot be made secretly without publicity. Publicity can place the people on guard as to how discretion is exercised. In the name of rule of law, judges must perform their functions in providing safeguards against any possible inappropriate handling of discretionary power.

Malaysia's Attorney General is clothed with a very wide constitutional power in which he can exercise his discretion relating to criminal prosecution almost absolutely. However, the dual role he played tilted the scale of benefit towards the executive, and in particular, the government of the day. Some measures need to be taken to improve the standing of the Attorney General where recent events may have caused a dent in the trust the public held towards the office.

The followings are some commendable recommendations for considerations.

\section{Separation of Attorney General's dual roles}

The recent controversy relating to the publication of the Memoir of the former Attorney General of Malaysia has revived the call to have the responsibility of Attorney General an advisor for the government advisor and that of the Public Prosecutor be separated (similar to the standing of the Attorney General and Crown Prosecutorial Service in the United Kingdom). For this to be possible, a constitutional amendment to Article 145 is the major step to be taken. Indeed, members of parliament of both political divides have expressed their willingness to support this in the event proposed in the Dewan Rakyat. The question is, does Malaysia has the political will to do so?

To achieve political independence, Attorney General as a political appointee may not be the appropriate person to decide on the prosecution. He must be the executive legal advisor and at the same time, Public Prosecutor. The separation of these roles of the Attorney General may overcome the following issues. First, the decision on prosecution in controversial or politically sensitive circumstances. Without the benefit of separation of roles, there will be an impending debate whether the determination of the Attorney General to prosecute or not is based on political partisanship. This argument will damage public confidence in the administration of criminal law in the country.

Consequently, if these two roles are successfully separated, removing prosecution from political influence, would naturally be the best measure to be taken. The discussion above indicates that the Attorney General is a servant of the Prime Minister and hence acts 
according to the will of the executive. Thus, it is paramount to ensure that the Public Prosecutor remains apolitical yet accountable in his decision making.

Lessons from Australia perhaps can be learned. To ensure independence in the prosecution of criminal cases, the Attorney General 's office and that of the Deputy Public Prosecutors (DPP) is separated where most of the Attorney General's functions in matters of criminal prosecution are transferred to the latter by the force of Act of Parliaments. The DPP Offices were empowered to initiate, conduct and terminate prosecutions. There are also provisions allowing the DPPs' offices to publish guidelines and to provide directions relating to prosecution of cases. Australia hence achieves the dual objective i.e., independence in prosecution and establishing consistency and transparency in the of course the exercise of prosecutorial discretion (Yang, 2013).

Hence, in the context of Malaysia, reform has to be made so as to ensure Attorney General is independent and not subject to the instruction of his political masters.

\section{Increase of Transparency in the Exercise of Power to Prosecute}

The process of prosecutions in Malaysia is shrouded with secrecy and indeed lacks transparency. Attorney General is not bound to give reasons for his decision. This problem of secrecy is not unique to Malaysia. Australia once experienced this. It was reported by the Australian Law Reform Commission in 1980 that:

The process of prosecutions in Australia at both State and Federal level is probably the most secretive, least understood and most poorly documented aspect of the administration of criminal justice (ALRM, 1980).

To overcome this problem of secrecy and lack of transparency, the new law in Australia empowers the Deputy Public Prosecutors to publish guidelines relating to prosecution. This will increase the due process and create trust among members of the public. Publishing guidelines were acknowledged as measures that increase transparency and accountability and are practiced by the Attorney General's office in Canada (Layton, 2002). There exist different views as to the workability of such guidelines. Some are of the view that having guidelines as such is unnecessary and undesirable as it promotes inflexible and static policies. Publications provide beneficial avenue to increase transparency and accountability in the exercise of prosecutorial discretion which consequently realize the call for justice and rule of law.

Nevertheless, in this context, the challenges will be: how far should one scrutinize or restrain exercise of discretion? The crucial balance to be achieved will be between achieving efficiency in decision making and transparency, accountability, independence and fairness in the exercise of discretion.

\section{Placing Attorney General's accountability to Parliament}

The discussion above reflects that the appointment and dismissal of an Attorney General are at the hand of his political master, the Prime Minister. Hence, the accountability of the Attorney General is to the Prime Minister for his action or inaction. This has to change where the Attorney General instead has to be accountable and answerable to Parliament. Like the 
member of the judiciary, he has to decide without fear or favor. Hence it is only natural that his position is safeguarded by the Parliament.

\section{Conclusion}

Despite the above recommendations, history has recorded that the position of the Attorney General of Malaysia has for several times been rattled by Constitutional Amendments. There have been changes made to the legal character of the Attorney General. Safeguards against dismissal earlier accorded to him and the manner of selection have been changed to make him into the political servant of the Executive. The position of the Attorney General needs to be restored and this can be done by amending the constitution. We pray the government of the day has the much-needed political will to restore the Attorney General's position so that the Attorney General indeed will be a worthy keeper of the Criminal Justice System in the country.

\section{Acknowledgement}

This research received no specific grant from any funding agency in the public, commercial, or not-for profit sectors.

\section{Reference}

Abu Bakar, B. (2015). The Attorney General as Public Prosecutor in Malaysia: From QuasiJudicial to Executive. IIUMLJ, 23(2), 345-381.

Acton, L. (1887). Letter to Archbishop Mandell Creighton. Retrieved from https://history.hanover.edu/courses/excerpts/165acton.html

Applegate, A. G. (1982). Prosecutorial Discretion and Discrimination in the Decision to Charge. Maurer Faculty, 35-88. Retrieved from https://www.repository.law.indiana.edu/facpub/1018

Australian Law Reform Commission. (1980). Sentencing of Federal Offenders. Report no 15.

Boolell, S. S. (2013). Prosecutorial Discretion and Its Challenges. Commonwealth Law Bulletin, 39(1), 5-15. doi:10.1080/03050718.2012.751192

Boyd, C. L., Nelson, M. J., Boldt, E. D., \& Ostrander, I. (2021). The Politics of Federal Prosecution. New York: Oxford University Press.

Chan, G. (2013). Prosecutorial Discretion and the Legal Limits in Singapore. Singapore Academy of Law Journal, 25(1), 15-50. Retrieved from http://ink.library.smu.edu.sg/sol_research/1185

Davies, K. (1969). Discretionary Justice: A Preliminary Inquiry. Baton Rogue: Louisiana State University Press.

Fisher, D. (1993). Fifth Amendment-Prosecutorial Discretion No Absolute: Constitutional Limits on Decision Not to File Substantial Assistance Motions. Journal of Criminal Law and Criminology, 83(4), 744-772. Retrieved from https://scholarlycommons.law.northwestern.edu/cgi/ viewcontent.cgi?article $=6756 \&$ context $=$ jclc

Frankel, M. E. (1973). Criminal Sentences: Law Without Order. Hill \& Wang.

Hoecke, M. V. (2015). Methodology of Comparative Legal Research. Law and Method, 1-35.

Hoecke, M. V. (2016). Methodology of Comparative Legal Research. Law and Method, https://doi.org/10.5553/rem/.000010.

House of Commons. (1951). Parliamentary Debates, 483(683). 
Imam, M. (2000). Power to Prosecute and Enter Nolle Prosequi Under the Federal Constitution and the Laws of Malaysia: A Viewpoint. Journal of the Indian Law Institute, 42(1), 40-55.

International Commission of Jurist. (1959). Rule of Law in a Free Society. New Delhi. Retrieved from https://www.icj.org/wp-content/uploads/1959/01/Rule-of-law-in-a-free-societyconference-report-1959-eng.pdf

Langbein, J. H. (1973). The Origin of Public Prosecution at Common Law. American Journal of Legal History, 17, 313-335. Retrieved from https://digitalcommons.law.yale.edu/ cgi/viewcontent.cgi?article $=1550 \&$ context=fss_papers

Layton, D. (2002). The Prosecutorial Charging Decision. Criminal Law Quarterly, 447-482.

Marvin, E., Frankel, C. S. (1973). Criminal Sentences: Law Without Order.

Rosenberg, M. (2009). The Attorney General and the prosecution function in the twenty first century. Queen's Law Journal , 43, 813-862.

Sanders, A. (1986). An Independent Crown Prosecution Service. Criminal Law Review, 28(4), 16-27.

Shahizam, S. (2020). Wither Non-Justiciability? An Argument for Judicial Review of Prosecutorial Discretion in Light of the Basic Structure . Malayan Law Journal, 2, cxliclxxii.

Sheridan, L. A. (1987). The Constitution of Malaysia (4 ed.). Singapore: Malayan Law Journal.

Smits, J. M. (2017). What is Legal Doctrine? On the Aims and Methods of Legal-Dogmatic Research (September 1, 2015). In H.-W. M. Rob van Gestel, Rethinking Legal Scholarship: A Transatlantic Dialogue, (pp. 207-228). New York: Cambridge University Press.

Stenning, P. C. (2009). Discretion, Politics, and the Public Interest in "High-Profile" Criminal Investigations and Prosecutions. Canadian Journal of Law and Society / La Revue Canadienne Droit et Société , 24(3), 337-366. doi:https://doi.org/10.1017/S0829320100010073

Stith, K. (2008). The Arc of the Pendulum: Judges, Prosecutors, and the Exercise of Discretion. Yale L.J., 1420-1497. Retrieved from https://digitalcommons.law.yale.edu/cgi/viewcontent.cgi?article=2264\&context=fss_ papers

Yang, K. (2013). Public Accountability of Public Prosecutions. , Vol.20, (No.1), p.29-30. Murdoch University Law Review, 20(1), 28-75. Retrieved from http://researchrepository.murdoch.edu.au/id/eprint/22599 